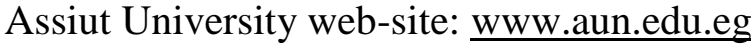

\title{
AMYLOIDOSIS IN DROMEDARY CAMEL (ONE-HUMPED) IN ASWAN SLAUGHTER HOUSES, EGYPT
}

\author{
MARWA A. AHMED \\ Department of Pathology, Faculty of Veterinary Medicine, Aswan University, Egypt
}

Received: 14 April 2020; Accepted: 29 June 2020

\begin{abstract}
The amyloidosis are a group of disorders in which soluble proteins aggregate and deposit extracellular in tissue as insoluble fibrils, causing progressive organ dysfunction. A definitive diagnosis of amyloidosis is based on the histological presence of amyloid substance in tissue specimens. Under light microscope, amyloid substance appears as homogenous pink extracellular deposits in hematoxylin and eosin. On stained sections with Congo red, the extracellular deposits appear orange red in color. In this study, amyloidosis was diagnosed by histopathological examination under light microscope in the liver and kidney tissues from 30 adult dromedary camels (one-humped) collected from a total 50 adult dromedary camels (onehumped) that were presented for slaughter at Draw abattoir in Aswan Governorate between 2018 and 2019. Amyloid deposits in the kidney were located around Bowmans capsule, mesangial areas and peritubular interstitial tissues. Amyloid was also seen in liver were located around blood vessels and along the sinusoids. Concurrent lesions of amyloid in liver include fatty changes, hydropic degeneration and necrosis. Also Concurrent lesions with amyloid in kidneys include proliferative glomerulonephritis and necrosis in tubules.
\end{abstract}

Keywords: Camel, Amyloid, Dromedary camel

\section{INTRODUCTION}

Amyloidosis constitutes a group of diseases in which proteins deposit extracellularly in tissues as insoluble fibrils (Dember, 2006). Amyloid deposits may be localized, organ-limited or generalized and can affect any tissue or organ type (Urban

Corresponding author: MARWA A. AHMED

E-mail address: marwaahmad78@yahoo.com

Present address: Department of Pathology, Faculty of

Veterinary Medicine, Aswan University, Egypt et al., 1993; Monzawa et al., 2002; Rocken and Shakespeare, 2002). Progressive organ involvement leads to organ malfunction and death usually resulting from renal and/or cardiac involvement. Liver and spleen are major sites of involvement (Monzawa et al., 2002; Park et al., 2003). Even when suspected clinically and radiologically, the diagnosis of amyloidosis mainly depends upon detection of amyloid deposits in tissue biopsy sections (Kim et al., 2003). 


\section{MATERIAL AND METHODS}

\section{-Material:}

The present study has been carried out on 30 adult Dromedary camels (one-humped) collected from a total 50 adult dromedary camels (one-humped) that presented for slaughter at Draw abattoir in Aswan Governorate between 2018 and 2019. Livers and kidneys were collected for processing.

\section{-Methods:}

The obtained tissue specimens were fixed in $10 \%$ neutral buffered formalin. The specimens routinely processed, paraffin embedded, sectioned at 4 - 5 micron thickness. The prepared slides were stained by $\mathrm{H} \& \mathrm{E}$ and Congo red stains (Bancroft and Stevans, 1993).

\section{RESULTS}

Amyloid deposits in renal and hepatic tissues in 30 adult Dromedary camels (onehumped). In H\&E stained, amyloid appeared pale eosinophilic, homogeneous extracellular material. In Congo red stained- sections, amyloid appeared orange red.

In kidneys: amyloidosis was diagnosed in kidneys by histopathological examination under light microscope. Amyloid deposited around Bowmans capsule (Figs. 1A, 1B), mesangial area (Figs. 2A, 2B) and at the peritubular interstitium tissues (Figs. 3A, 3B). Tubules adjacent to amyloid deposits were variably atrophied and were occasionally hydropic degeneration and necrosis (Fig. 3B). Amyloid deposits within glomeruli concurrent with expanding the mesangial area and proliferative glomerulonephritis (Fig.2A).

In Livers: amyloidosis was diagnosed in liver by histopathological examination under light microscope. Amyloids were located around blood vessels (Figs. 5A, 5B) and along the sinusoids (Figs. 4A, 4B). Fatty change (Figs. 4A, 4B, 5A, 5B), hydropic degeneration (Fig. 6A) and necrosis in liver cells (Fig. 6B) are concurrence with amyloid deposits. 

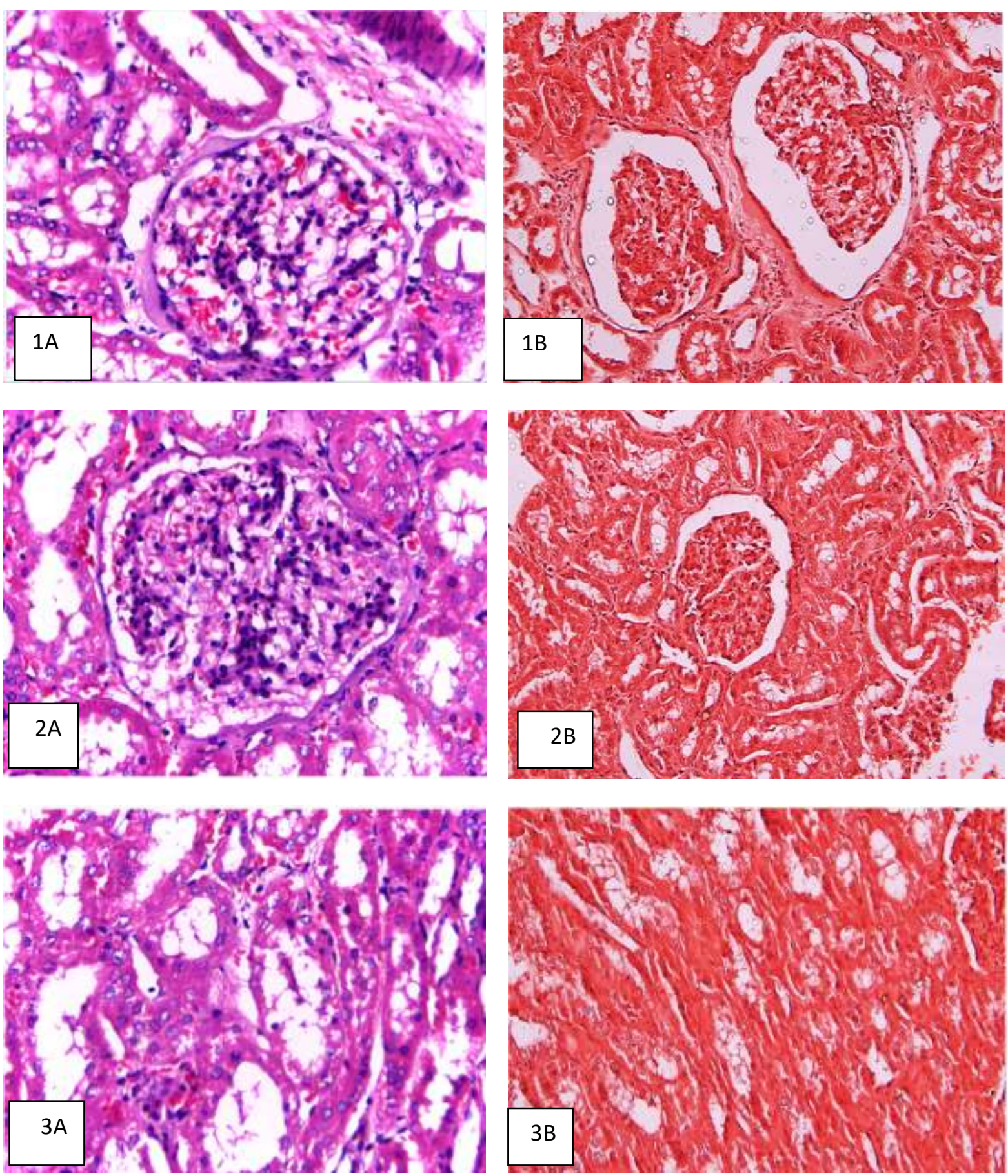

Fig. 1A: Kidney showing amyloidosis. Notice the presence of homogenous pink extracellular material deposits around Bowmans' capsule. H\&E stain. 10x40

Fig. 1B: Kidney showing amyloidosis. Notice the presence of homogenous orange red extracelluar material deposits around Bowmans'capsule. Congo red stain. 10x40.

Fig. 2A: Kidney showing amyloidosis. Notice the presence of homogenous pink material deposits in the mesangium of glomerulus with proliferative glomerulonephritis. H\&E stain. 10x40.

Fig. 2B: Kidney showing amyloidosis. Notice the presence of homogenous orange red material deposits in the mesangium of glomerulus. Congo red stain. 10x10.

Fig. 3A: Kidney showing amyloidosis. Notice the presence of homogenous pink material deposits within the renal intersitium. H\&E stain. 10x40.

Fig. 3B: Kidney showing amyloidosis. Notice the presence of homogenous orange red material deposits within the renal intersitium. Tubules adjacent to amyloid deposits were variably atrophied. Congo red stain. 10x10. 

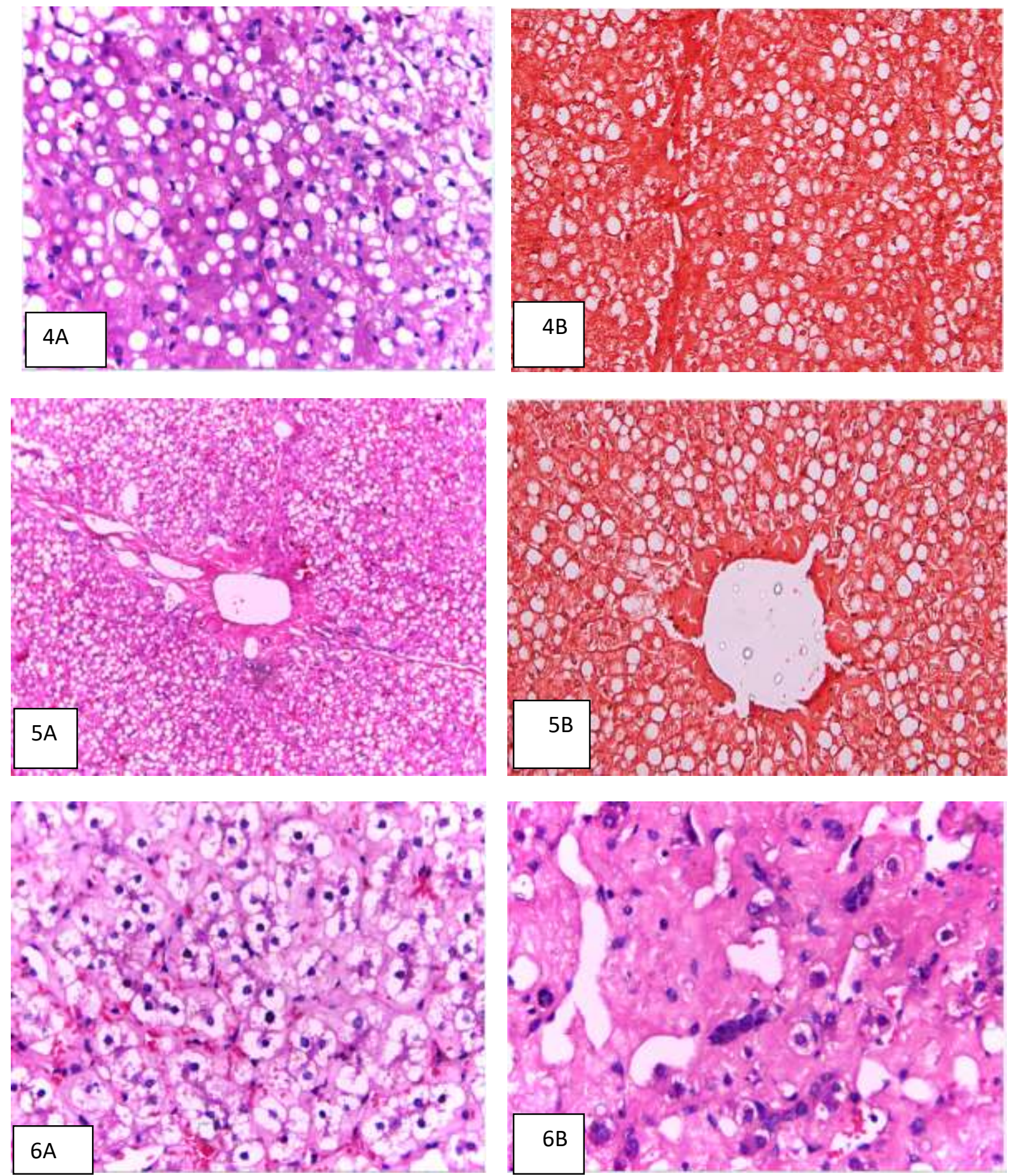

Fig. 4A: Liver showing amyloidosis. Notice the presence of homogenous pink extracelluar material deposits along the sinusoids. Fatty change with amyloid deposits. H\&E stain. 10x10.

Fig. 4B: Liver showing amyloidosis. Notice the presence of orange red extracellular material deposits along the sinusoids with fatty change. Congo red stain. 10x10.

Fig. 5A: Liver showing amyloidosis. Notice the presence of homogenous pink extracellular material deposits around central vein with fatty change. H\&E stain. 10x10.

Fig. 5B: Liver showing amyloidosis. Notice the presence of orange red extracellular deposits around central vein with fatty change. H\&E stain. $10 \times 10$.

Fig. 6A: Liver showing amyloidosis. Notice the presence of homogenous pink extracellular material deposits along the sinusoids. Hydropic degeneration with amyloid deposits. H\&E stain. 10x40.

Fig. 6B: Liver showing amyloidosis. Notice the presence of homogenous pink extracellular material deposits along the sinusoids. Necrosis with amyloid deposits. H\&E stain. 10x40. 


\section{DISCUSSION}

In this study amyloidosis was diagnosed in the liver and kidney tissues in 30 adult Dromedary camels (one-humped). Nakamura et al. (1995) also found cerebral senile plaques in an aged female camel (two-humped) of more than 20 years old.

Amyloid is a complex glycoprotein, comprising fibrillar and globular proteins, linked to polysaccharides, moreover, the amino acid content in amyloid in different from that in serum and tissue proteins, hyaline, and collagen (Shishkin, 2008). Amyloid protein and carbohydrate fractions are tightly bound to each other (Segev et al., 2012). The cells of the mononuclear phagocyte system usually inactivate amyloid; however, either decrease in their activity or amyloid hyperproduction result in amyloid deposition in the tissue (Naumenko, 2005). primary amyloid (Immunocytedyscrasia) is the most common form of amylodosis in humans but not in animals, on other hand secondary amyloid (reactive systemic amylodosis) is the most common form of amylodosis in animals, and the amyloid is deposited in kidney, liver, spleen and lymphnodes (Zachary and McGavin, 2012). Amylodosis development depends on prolonged, abnormally high concentration of the serum amyloid A (SAA) protein in the blood serum, which is normally low (Real et al., 2014). In blood, SAA increased only during periods of active, systemic inflammation (Lozanski et al., 1996). Inflammatory conditions cause release of amyloidogenic cytokines (Colegrovr et al., 2009). The mechanisms of amyloidogenesis are variable and include abnormal protein production, overproduction or decreased excretion of wild-type proteins and hereditary mutation (Szczepankiewicz et al., 2018).
Moreover, stress has been proposed as a factor in development of amyloidosis in some species (Cowan and Johnson, 1970; Germann et al., 1990; Papendick et al., 1997). The tissue tropism of amyloid deposition in affected camels was similar to that reported in other species (DiBartola and Benson, 1989). Kulikov et al., 2017 reported that the initial stages of amyloidosis in Shar-Pei dogs is characterized by glomerular amyloid deposits; then, the process spreads to the tunica propria of the tubules, whereas pronounced disease involves the interstitial connective tissue between tubules. This process lead to atrophy of the tubules and glomeruli, extending to their disintegration. Also, in case of hepatic amyloidosis, amyloid is deposited in parenchyma, along the sinusoids within the space of Disse, or in blood vessel walls. Hepatocytes are severely compressed by extensive accumulation of amyloid and they may atrophy or nearly disappear (Yong Moon Shin, 2011).

\section{ACKNOWLEDGEMENT}

Dr. Sary Kh. Abd-Elghaffar, professor of pathology and clinical pathology. Faculty of Veterinary Medicine, Assiut University. Egypt

Dr. Marwa M. Safwat, Faculty of Veterinary Medicine, Assiut University. Egypt

\section{REFERENCES}

Bancroft, J.D. and Stevans, A. (1993): Theory and practice of histologic techniques. 3rd Ed. Long Man Group limited. pp. 113-305.

Colegrove, K.M.; Gulland, F.M.D.; Harr, K.; Naydan, D.K. and Lowenstine, L.J. (2009): Pathological features of amyloidosis in Stranded California Sea Lions (Zalophuscalifornianus). 
J.Comp. Path. 2009, Vol. 140, 105112.

Cowan, D.F. and Johnson, W.C. (1970): Amyloidosis in the white Pekinduck. I. Relation to social environmental stress. Laboratory Investigation, 23, 551-555.

Dember, L.M. (2006): Amyloidosisassociated kidney disease. J Am SocNephrol. Dec; 17(12): 3458-71. Epub 2006 Nov 8.

DiBartola, S.P. and Benson, M.D. (1989): The pathogenesis of reactive systemic amyloidosis. Journal of Veterinary Internal Medicine, 3, 31-41.

Germann, P.G.; Kohler, M.; Ernst, H.; Baumgart, H. and Mohr, U. (1990): The relation of amyloidosis to social stress induced by crowding in the Syrian hamster (Mesocricetusauratus). Zeitschrift fur Versuchstierkunde, 33, 271-275.

Kim, S.H.; Han, J.K.; Lee, K.H.; Won, H.J.; Kim, K.W.; Kim, J.S.; Park, C.H. and Choi, B.I. (2003): Abdominal amyloidosis: spectrum of radiological findings. Clin Radiol. Aug; 58(8): 610-20.

Kulikov, E.V.; Vatnikov, Y.A.; Parshina, V.I.; Sotnikova, E.D.; Vilkovyskiy, I.F.; Popova, I.A.; Kochneva, M.V. and Karamyan, A.S. (2017): Special Aspects ofthe Pathohistological Diagnostics of Familial Shar-Pei Amyloidosis. Asian Journal of Pharmaceutics• Jan-Mar 2017 (Suppl) - 11 (1) | S152.

Monzawa, S.; Tsukamoto, T.; Omata, K.; Hosoda, K.; Araki, T. and Sugimura, K. (2002): A case with primary amyloidosis of the liver and spleen: radiologic findings. EurJ Radiol, 41:237-241.

Lozanski, G.; Jiang, S.L.; Samols, D. and Kushner, I. (1996): C-reactive protein and serum amyloid A mRNA stability following induction by cytokines. Cytokine, 8, 534-540.

Nakamura, S.; Nakayama, H.; Uetsuka, K.; Sasaki, N.; Uchida, K. and Goto, N.
(1995): Senile plaques in an aged two-humped (Bactrian) camel (Camelusbactrianus).

ActaNeuropathol. 90(4):415-8.

Amiloidozzhivotnykh [Amyloidosis in animals]. Veterinariya, 2:49-53.

Park, M.A.; Mueller, P.S.; Kyle, R.A.; Larson, D.R.; Plevak, M.F. and Gertz, M.A. (2003): Primary (AL) hepatic amyloidosis: clinical features and natural history in 98patients. Medicine (Baltimore), 82:291-298.

Papendick, R.E.; Munson, L.; O'Brien, T.D. and Johnson, K.H. (1997): Systemic AA amyloidosis in captive cheetahs (Acinonyxjubatus). Veterinary Pathology, 34, 549-556.

Real de Asúa, D.; Costa, R.; Galván, J.M.; Filigheddu, M.T.; Trujillo, D. and Cadiñanos, J. (2014): Systemic AA amyloidosis: $\quad$ Epidemiology, diagnosis, and management. ClinEpidemiol, 6:369-77.

Rocken, C. and Shakespeare, A. (2002): Pathology, diagnosis and pathogenesis of AA amyloidosis. Virchows Arch, 440:111-122.

Segev, G.; Cowgill, L.D.; Jessen, S.; Berkowitz, A.; Mohr, C.F. and Aroch, I. (2012): Renal amyloidosis in dogs: A retrospective study of 91 cases with comparison of thedisease between Shar-Pei and non-Shar-Pei dogs. J Vet Intern Med, 26:259-68.

Shishkin, A.N. (2008): Amiloidnyebolezni [Amyloid diseases]. Med XXI Vek, 9:44-51.

Szczepankiewicz, B.; Pasławska, U.; Grzegory, M.; Jonkisz, P.; Borecka, P.; Marzec, M.; Brzozowska, M. and Nowak, M. (2018): Canine renal amyloidosis: A case report. Med. Weter., 74 (5), 320-323.

Urban, B.A.; Fishman, E.K.; Goldman, S.M.; Scott, W.W.; Jr Jones, B.; Humphrey R.L. and Hruban, R.H. (1993): CT evaluation of amyloidosis: spectrum of disease. adiographics. Nov; 13(6):1295-308. 
Yong Moon Shin (2011): Hepatic Zachary, J.F. and McGavin, M.D. (2012): amyloidosis. The Korean Journal of Hepatology, 17:80-83DOI: 10.3350/ kjhep.2011.17.1.80.

Pathologic basis of veterinary disease. Fifthedition. Copy right.

\section{داء النشواني في الإبل الجملاني (سنام واحد) في مسلخ أسوان ، مصر}

\section{مروه أحمد}

E-mail: marwaahmad78@yahoo.com Assiut University web-site: www.aun.edu.eg

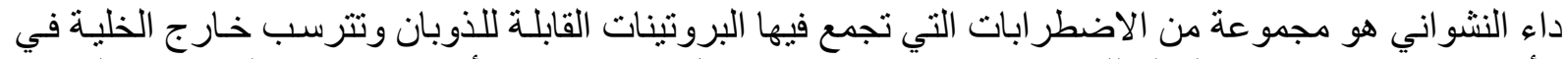

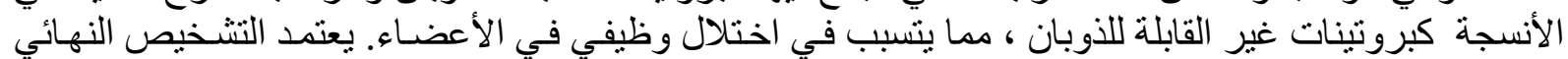

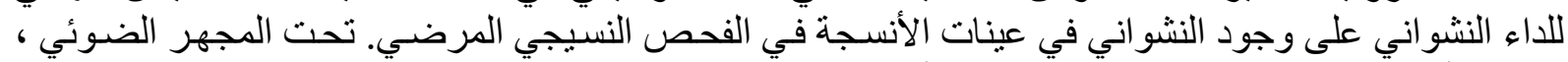

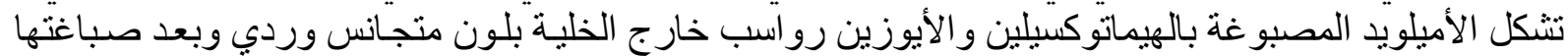
بالأحمر الكونغولي تكون الرواسب خارج الخلية برتقالية حمر اء اللون. في هذه الدر اسة تم تشخيص داء داء النشواني

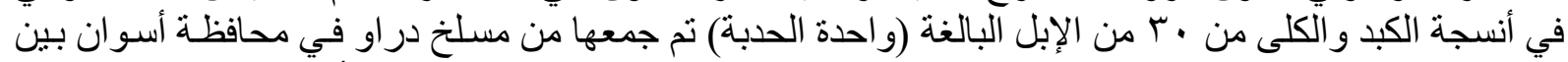

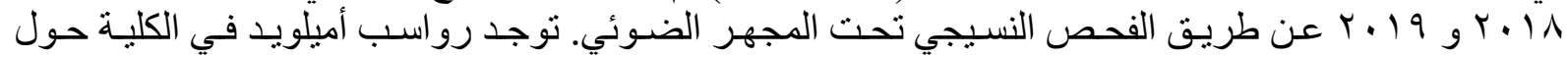

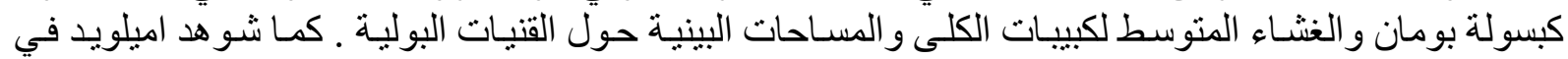

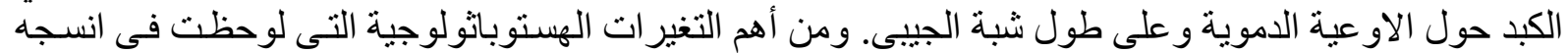

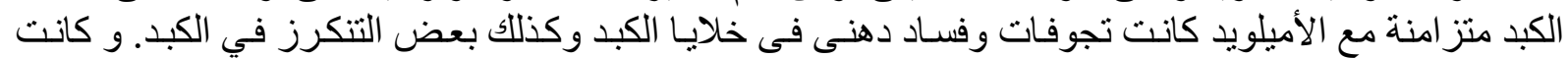
الآفات المنز امنة مع اميلويد في الكلى التهاب كبيبات الكلى التكاثري وكذلك بعض التهات التنكرز للخلايا الطلائية المبطنة

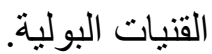

